\title{
KILLER TOXIN OF SACCHAROMYCES CEREVISIAE Y500-4L ACTIVE AGAINST FLEISCHMANN AND ITAIQUARA COMMERCIAL BRANDS OF YEAST
}

\author{
Giselle A.M. Soares*; Hélia H. Sato
}

Departamento de Ciência de Alimentos, Faculdade de Engenharia de Alimentos, Universidade Estadual de Campinas, Campinas, SP, Brasil

Submitted: October 02, 1998; Returned to authors for corrections: March 03, 1999; Approved: May 11, 1999

\begin{abstract}
The strain Saccharomyces cerevisiae Y500-4L, previously selected from the must of alcohol producing plants and showing high fermentative and killer capacities, was characterized according to the interactions between the yeasts and examined for curing and detection of dsRNA plasmids, which code for the killer character. The killer yeast $S$. cerevisiae Y500-4L showed considerable killer activity against the Fleischmann and Itaiquara commercial brands of yeast and also against the standard killer yeasts K2 (S. diastaticus NCYC 713), K4 (Candida glabrata NCYC 388) and K11 (Torulopsis glabrata ATCC 15126). However S. cerevisiae Y500-4L showed sensitivity to the killer toxin produced by the standard killer yeasts K8 (Hansenula anomala NCYC 435), K9 (Hansenula mrakii NCYC 500), K10 (Kluyveromyces drosophilarum NCYC 575) and K11 (Torulopsis glabrata ATCC 15126). No M-dsRNA plasmid was detected in the S. cerevisiae Y500-4L strain and these results suggest that the genetic basis for toxin production is encoded by chromosomal DNA. The strain S. cerevisiae Y500-4L was more resistant to the loss of the phenotype killer with cycloheximide and incubation at elevated temperatures $\left(40^{\circ} \mathrm{C}\right)$ than the standard killer yeast $S$. cerevisiae $\mathrm{K} 1$.
\end{abstract}

Key words: Killer yeast, Saccharomyces cerevisiae, killer toxin

\section{INTRODUCTION}

The killer system in yeasts has been extensively investigated since it was first described in Saccharomyces cerevisiae by Bevan and Makower (1). Killer strains secrete a protein toxin which is lethal to sensitive strains of the same genus and, less frequently, strains of different genera (10). Among the yeasts, killer, sensitive, and neutral strains have been described. Eleven distinct patterns of the range of killer activity against killer yeast have been found
(K1-K11) according to the interaction between the killer yeasts $(12,15)$.

Genetic studies have shown that the killer phenotype of $S$. cerevisiae is inherited cytoplasmically and has been linked to the presence of a double stranded RNA (dsRNA) associated with virus-like particles within the cytoplasm of the killer cells. However, dsRNA need not always be the determinant. In other genera, like Kluyveromyces lactis, the information for the killer phenotype is carried by linear dsDNA $(6,11)$. The killer character

\footnotetext{
* Corresponding author. Mailing address: Departamento de Ciência de Alimentos, Faculdade de Engenharia de Alimentos, Universidade Estadual de Campinas - UNICAMP, CP 6121, Campinas, SP, Brasil. Fax (+5519) 788 7890. E-mail: gisoares@obelix.unicamp.br
} 
of Candida sp. $(13,14)$ and Hansenula anomala (7) is encoded by chromosomal genes, not by extrachromosomal ones.

In Saccharomyces cerevisiae, two distinct dsRNA species exist: L-dsRNA (4.6-4.8 Kb) and M-dsRNA $(1.0-1.8 \mathrm{~Kb})(12)$. It has been established that LdsRNA encodes the major virus-like particle capsid protein, and M-dsRNA encodes the killer toxin synthesis $(2,3)$. L-dsRNA encodes a protein for encapsidation of M-dsRNA and plays an essential role in maintenance or expression of the killer phenotype (3). Kitano et al. (8) furthermore observed two new killer types belonging to Saccharomyces. Using tetrad analysis, their killer genes were found to be encoded on chromosomal DNA. One gene, designated KHR, was on chromosome IX and another, designated as KHS, was on chromosome V (4).

The purpose of this investigation was to characterize the previously isolated killer strain $S$. cerevisiae Y500-4L, which shows high fermentative capacity.

\section{MATERIALS AND METHODS}

Yeast strains. Saccharomyces cerevisiae Y5004L and Hansenula sp. Y66-1 killer yeasts, previously isolated from the must of alcohol producing plants (9). Two commercial brands of yeast (Fleischmann e Itaiquara) were used as sensitive strains. The standard killer yeasts are listed in Table 1.

Table 1- Standard killer yeast strains used

\begin{tabular}{lc}
\hline Strains & Killer type \\
\hline Saccharomyces cerevisiae KL88 & $\mathrm{K} 1$ \\
Saccharomyces diastaticus NCYC 713 & $\mathrm{K} 2$ \\
Saccharomyces capensis NCYC 761 & $\mathrm{K} 3$ \\
Candida glabrata NCYC 388 & $\mathrm{K} 4$ \\
Debaryomyces vanrij NCYC 577 & $\mathrm{K} 5$ \\
Kluyveromyces marxianus NCYC 587 & $\mathrm{K} 6$ \\
Pichia membranaefaciens NCYC 333 & $\mathrm{K} 7$ \\
Hansenula anomala NCYC 435 & $\mathrm{K} 8$ \\
Hansenula mrakii NCYC 500 & $\mathrm{K} 9$ \\
Kluyveromyces drosophilarum NCYC 575 & $\mathrm{K} 10$ \\
Torulopsis glabrata ATCC 15126 & $\mathrm{K} 11$ \\
\hline
\end{tabular}

Media. YEPD medium (1.0\% yeast extract, $2.0 \%$ peptone, $2.0 \%$ glucose $)$ and $\mathrm{YM}$ medium $(0.3 \%$ yeast extract, $0.3 \%$ malt extract, $0.5 \%$ peptone, $1.0 \%$ glucose) were used for yeast culturing. YEPD-MB agar (YEPD containing $0.1 \mathrm{M}$ citrate-phosphate buffer $\mathrm{pH} 4.5,0.01 \%$ methylene blue and $2.0 \%$ agar) was used for the determination of killer phenotype.

Interaction between killer yeasts. Killing ability and resistance were determined by inoculating killer strains onto YEPD-MB agar and after incubation for 2 days at $25^{\circ} \mathrm{C}$ the sensitive yeast suspension, previously incubated on YEPD medium for 2 days at $25^{\circ} \mathrm{C}$, was sprayed onto YEPD-MB agar. The plates were incubated for 2 more days at $25^{\circ} \mathrm{C}$ and the strains with killer activity appeared surrounded by a clear zone.

Extraction and electrophoresis of doublestranded RNA plasmids. Extraction was performed by a modification of the method of Goto et al. (5). Yeast cells grown in YEPD medium were harvested and washed with $50 \mathrm{mM}$ EDTA ( $\mathrm{pH} 8.0$ ). After centrifugation at $5000 \mathrm{rpm}$ for 10 minutes, the cells were incubated for 1 hour at $60^{\circ} \mathrm{C}$ in $600 \mu l$ of a solution containing $25 \mathrm{mM}$ EDTA, $200 \mathrm{mM}$ Tris$\mathrm{HCl}(\mathrm{pH} 8.0), 25 \mathrm{mM} \mathrm{NaCl}$ and $1.0 \%$ sodium dodecyl sulfate. The cell suspension was then centrifuged and the aqueous phase treated twice with an equal volume of phenol, phenol-chloroform (1:1) and chloroform for extraction of the plasmids. The upper phase was transferred and precipitated with isopropanol (1:1). The precipitate was dissolved in buffer and analyzed by $1 \%$ agarose gel electrophoresis (75V, 0.7A for 2 hours).

Curing test. Killer yeast cells grown in YM medium were suspended in sterilized water $\left(10^{6}\right.$ cells/ $\mathrm{ml}$ ) and $10 \mu \mathrm{l}$ streaked onto YM agar with or without $0.2 \mathrm{ppm}$ cycloheximide. The plates were incubated at temperatures of $25^{\circ} \mathrm{C}$ (control), $37^{\circ} \mathrm{C}, 38.5^{\circ} \mathrm{C}$ or $40^{\circ} \mathrm{C}$ for 3 days. Colonies of the yeast which grew in each treatment were inoculated onto YM agar, and after incubation at $25^{\circ} \mathrm{C}$ for 36 hours, were replicaplated on YEPD-MB agar plates and then the sensitive yeast sprayed. After 2 days, the cured strains, which had lost their killer activity, were detected.

\section{RESULTS AND DISCUSSION}

Interaction between yeasts. Killing ability and resistance of $S$. cerevisiae Y500-4L, previously selected (9) as being a strain showing high fermentative capacity, were determined by interaction between yeasts. The results are shown in Table 2. The 
killer yeast $S$. cerevisiae Y500-4L showed considerable killer activity against the Fleischmann and Itaiquara commercial brands of yeast, suggesting that this strain could be a potential competitor in alcoholic fermentations using these commercial brands as starter cultures. It also showed killer activity against the standard killer yeasts $\mathrm{K} 2, \mathrm{~K} 4$ and $\mathrm{K} 11$. This killer character was similar to that of the K1 type killer. However, the strain Y500-4L showed sensitivity to the killer toxin produced by the standard killer yeasts $\mathrm{K} 8, \mathrm{~K} 9, \mathrm{~K} 10$ and $\mathrm{K} 11$ and was immune to the action of the $\mathrm{K} 2, \mathrm{~K} 3$ and $\mathrm{K} 5$ killer toxins.

Extraction and electrophoresis of doublestranded RNA plasmids. Double-stranded RNA plasmids of killer strains were analyzed by agarose gel electrophoresis (Fig. 1). Standard killer type strains $\mathrm{K} 1, \mathrm{~K} 2$ and $\mathrm{K} 3$ contain the two species of plasmid previously reported (15). The larger species (L-dsRNA) had a molecular weight of $5.0 \mathrm{~Kb}$; the killer type strain $\mathrm{K} 1$ showed the presence of M1dsRNA with $1.8 \mathrm{~Kb}$ and the strains $\mathrm{K} 2$ and $\mathrm{K} 3$ showed M2 and M3-dsRNA with $1.4 \mathrm{~Kb}$. The molecular weights of each species of dsRNA were similar to those described by Wickner (12).

The killer strain S. cerevisiae Y500-4L showed the presence of L-dsRNA with $5.0 \mathrm{~Kb}$ but no MdsRNA plasmid was detected. This result was the same as that obtained for another strain of $S$. cerevisiae, Y-9, described by Kitano (8), suggesting that the genetic basis for toxin is encoded by chromosomal DNA in these strains.

Fig. 1 also shows the result of the electrophoretic analysis of plasmid samples from Hansenula sp. Y66-1. No plasmids were detected. According to Kagiyama (7), the killer character of this genus is encoded by chromosomal genes.

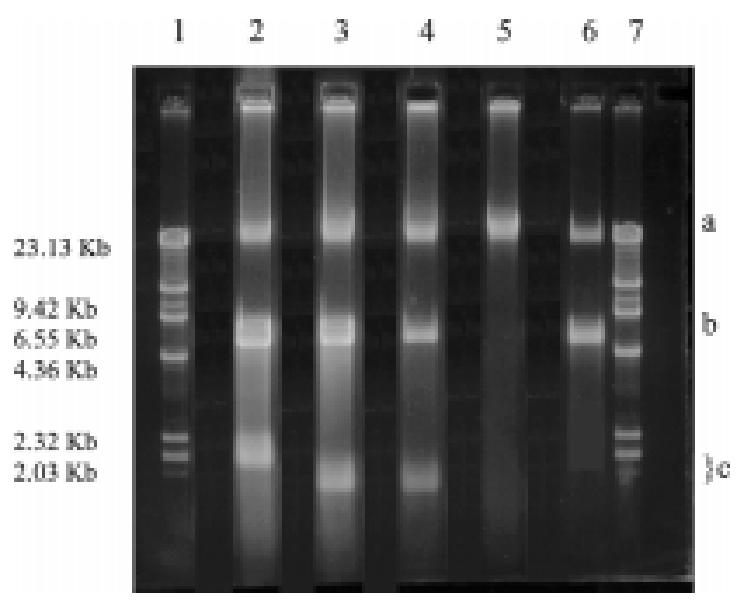

Figure 1-Agarose gel electrophoresis of dsRNA from killer yeasts. a- DNA; b- L-dsRNA; c- M-dsRNA;

1 and 7- $\lambda$ HindIII (molecular weight marker); 2 - standard killer yeast type K1; 3- standard killer yeast type K2; 4- standard killer yeast type K3; 5- strain Y66-1; 6- strain Y500-4L.

Table 2- Killing reaction of killer yeast against various yeasts

\begin{tabular}{lccccccccccccc}
\hline $\begin{array}{l}\text { Strains } \\
\text { Seeded }\end{array}$ & K1 & K2 & K4 & K6 & K7 & K8 & K9 & K10 & K11 & Y66-1 & Y500-4L & Fleisch. & Itaiquara \\
Killer strains & & & & & & & & & & & & & \\
K1 & - & + & + & - & - & - & - & - & + & - & - & + & + \\
K2 & + & - & - & - & - & - & - & - & - & - & - & - & + \\
K3 & + & - & + & - & - & - & - & - & - & - & - & - & ++ \\
K4 & - & + & - & - & - & - & - & - & - & + & - & ND & ND \\
K5 & + & - & - & - & - & - & - & - & + & - & - & ND & ND \\
K6 & - & - & - & - & - & - & - & - & - & - & - & ND & ND \\
K7 & - & - & + & - & - & - & - & - & + & + & - & ND & ND \\
K8 & + & + & ++ & - & - & - & - & - & ++ & + & ++ & ND & ND \\
K9 & ++ & ++ & ++ & - & - & - & - & - & ++ & + & ++ & ND & ND \\
K10 & + & + & ++ & - & - & - & - & - & + & + & + & ND & ND \\
K11 & + & ++ & - & - & - & - & - & - & - & ++ & + & ++ & ++ \\
Y66-1 & - & - & ++ & - & - & - & - & - & ++ & - & - & - & - \\
Y500-4L & - & ++ & + & - & - & - & - & - & + & - & - & +++ & ++++ \\
\hline
\end{tabular}

- = No killing activity

$+=$ Killing activity. Each $+=3 \mathrm{~mm} \mathrm{f}$ (clear zone)

ND indicates that the test was not carried out. 
Curing test. The results are shown in Table 3. The curing of the phenotype means the loss of killer toxin production by cycloheximide treatment or temperature.

Table 3- Curing of killer yeasts

\begin{tabular}{|c|c|c|c|c|}
\hline \multicolumn{5}{|c|}{ Methods of curing } \\
\hline & lohexin & emp. 37 & mp. 38 . & emp. $40^{\circ} \mathrm{C}$ \\
\hline \multicolumn{5}{|l|}{ Strains } \\
\hline K1 & - & $75 \%$ & $95 \%$ & - \\
\hline Y500-4 & $55 \%$ & $0 \%$ & $0 \%$ & $40 \%$ \\
\hline Y66-1 & $0 \%$ & - & - & - \\
\hline
\end{tabular}

The standard killer yeast K1 S. cerevisiae was cured easily by incubation at elevated temperature. At $37^{\circ} \mathrm{C}$ and $38.5^{\circ} \mathrm{C}, 75 \%$ and $95 \%$ respectively of curing were obtained. It did not grow in $0.2 \mathrm{ppm}$ cycloheximide or at $40^{\circ} \mathrm{C}$.

The strain $S$. cerevisiae Y500-4L was shown to be more resistant to curing than killer standard K1. Only $40 \%$ of curing was obtained when incubated at $40^{\circ} \mathrm{C}$ or $55 \%$ when grown in $0.2 \mathrm{ppm}$ cycloheximide. These results indicated that this strain is more resistant to the loss of killer capacity.

The strain Hansenula sp. Y66-1 was not cured by cycloheximide treatment and did not grow at elevated temperature $\left(37-40^{\circ} \mathrm{C}\right)$. These results were expected because the killer character in this genus is encoded by chromosomal genes.

\section{ACKNOWLEDGMENTS}

The authors thank CNPq for their financial support.

\section{CONCLUSIONS}

The killer strain S. cerevisiae Y500-4L, which have high fermentative capacity, was characterized. This yeast showed considerable killer activity against the Fleischmann and Itaiquara commercial brands of yeast and also against other genera like Candida, conferring a selective advantage over sensitive strains competing to grow in the same environment.

No M-dsRNA plasmid was detected in the strain Y500-4L, suggesting that the genetic basis for toxin production is encoded by chromosomal DNA. This result was in accordance with the greater resistance to treatments for the loss of the capacity to produce killer toxin. These results showed a potential use of this competitive yeast in alcoholic fermentation.

\section{RESUMO}

\section{Toxina "killer" de Saccharomyces cerevisiae Y500-4L ativa contra leveduras comerciais Fleischmann e Itaiquara}

A linhagem de Saccharomyces cerevisiae Y5004L com alta capacidade fermentativa e atividade "killer", previamente selecionada de mosto de fermentação de usina de álcool, foi caracterizada quanto ao espectro de atividade e quanto à perda do caracter "killer". A linhagem "killer" de $S$. cerevisiae Y500-4L, mostrou alta atividade "killer" contra as leveduras comerciais Fleischmann e Itaiquara, e também contra as linhagens "killer" padrões K2 ( $S$. diastaticus NCYC 713), K4 (Candida glabrata NCYC 388) e K11 (Torulopsis glabrata ATCC 15126) e mostrou ser sensível às toxinas produzidas pelas leveduras padrões "killer" K8 (Hansenula anomala NCYC 435), K9 (Hansenula mrakii NCYC 500), K10 (Kluyveromyces drosophilarum NCYC 575) e K11 (Torulopsis glabrata ATCC 15126). A linhagem de $S$. cerevisiae Y500-4L não apresentou plasmídio M-dsRNA e, provavelmente, o caracter genético responsável pelo fenótipo "killer" é codificado por genes cromossomais. Em ensaios para a perda do fenótipo, a linhagem S. cerevisiae Y500$4 \mathrm{~L}$ apresentou maior resistência ao tratamento com cicloheximida e a temperatura elevada $\left(40^{\circ} \mathrm{C}\right)$ do que a levedura $S$. cerevisiae padrão "killer" K1.

Palavras-chave: Levedura "killer", Saccharomyces cerevisiae, toxina "killer"

\section{REFERENCES}

1. Bevan, E.A.; Makower, M. The physiological basis of the killer character in yeast. Proceeding of the IIth International Conference on Genetics, 1: 203, 1963.

2. Bostian, K.A.; Hopper, J.E.; Rogers, D.T.; Tipper, D.J. Translation analysis of the killer-associated virus-like particle dsRNA genome of $S$. cerevisiae: M dsRNA encodes toxin. Cell, 19: 403-414, 1980.

3. Bostian, K.A.; Sturgeon, J.A.; Tipper, D.J. Encapsidation of yeast killer double-stranded ribonucleic acids: dependence of M on L. J. Bacteriol., 143: 463-470, 1980.

4. Goto, K.; Iwase, T.; Kichise, K.; Kitano, K.; Totsuka, A.; Obata, T.; Hara, S. Isolation and properties of a chromosomedependent KHR killer toxin in Saccharomyces cerevisiae. Agric. Biol. Chem., 54: 505-509, 1990.

5. Goto, K.; Morikawa, S.; Sato, H.H.; Park,Y.K. Characteristics of the killer yeast n.337 isolated from alcohol fermentation mash in Brazil. J. Brew. Soc. Japan, 85: 895-899, 1990. 
6. Gunge, N.; Tamaru, A.; Ozawa, F.; Sakaguchi, K. Isolation and characterization of linear deoxyribonucleic acid plasmids from Kluyveromyces lactis and the plasmid-associated killer character. J. Bacteriol., 145: 382-390, 1981.

7. Kagiyama, S.; Aiba, T.; Kadowaki, K.; Mogi, K. New killer toxins of halophilic Hansenula anomala. Agric. Biol. Chem., 52: $1-7,1988$

8. Kitano, K.; Sato, M.; Shimazaki, T.; Hara, S. Occurrence of wild killer yeast in Japanese wineries and their characteristics. J. Ferment. Technol., 62: 1-6, 1984.

9. Nascimento, A.M. Isolamento e seleção de leveduras produtoras de fator killer para aplicação na produção de bebidas alcoólicas. Campinas, 1994. 74 p. (Ms. Thesis. Fac. Eng. de Alimentos, Universidade Estadual de Campinas).

10. Petering, J.E.; Symons, M.R.; Langridge, P.; Henschke, P.A Determination of killer yeast activity in fermenting grape juice by using a marked Saccharomyces wine yeast strain. App. Env. Microbiol., 57: 3232-3236, 1991.
11. Stark, M.; Boyd, A.; Mileham, A.J.; Romanos, M.A. The plasmid encoded killer system of Kluyveromyces lactis: a review. Yeast, 6: 1-29, 1990.

12. Wickner, R.B. Double-stranded and single stranded RNA virus of S. cerevisiae. Annu. Rev. Microbiol., 46: 347-375, 1992.

13. Yokomori, Y.; Akiyama, H.; Schimizu, K. Isolation of a wild Candida killer yeast with a novel killer property. Agric. Biol.Chem., 52: 2791-2796, 1988.

14. Yokomori, Y.; Akiyama, H.; Schimizu, K. Toxins of a wild Candida killer yeast with a novel killer property. Agric. Biol.Chem., 52: 2797-2801, 1988.

15. Young, T.; Yagiu, M. A comparison of the killer character in different yeasts and its classification. Antonie van Leeuwenhoek, 44: 59-77, 1978. 